ISSN 1814-1196

Научный вестник НГТУ

том 73, № 4, 2018, с. 59-78 http://journals.nstu.ru/vestnik

Science Bulletin of the NSTU

Vol. 73, No. 4, 2018, pp. 59-78

INFORMATICS, COMPPUTER ENGINEERING

AND CONTROL

UDC 550.837:517.958

DOI: 10.17212/1814-1196-2018-4-59-78

\title{
A study of equivalence of influences of varying thickness and conductivity in 3D-processing of airborne electromagnetic data in complex media*
}

\author{
N.V. KONDRATYEV ${ }^{a}$, D.S. KISELEV ${ }^{b}$, D.V. VAGIN ${ }^{c}$, M.G. PERSOVA ${ }^{d}$ \\ Yu.G. SOLOVEICHIK \\ Novosibirsk State Technical University, 20, K. Marx Prospekt, Novosibirsk, 630073, \\ Russian Federation, Department of Applied Mathematics

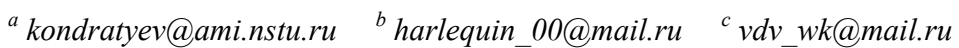 \\ 'persova@ami.nstu.ru ${ }^{e}$ soloveychik@ami.nstu.ru
}

\begin{abstract}
The paper is devoted to the problem of processing the airborne electromagnetic (AEM) data with a view to developing recommendations on parameterization of a geological medium for carrying out the geometric 3D-inversion of airborne data. The study is performed with the use of finite element 3D-modeling of transient EM fields induced by the helicopter AEM system in complex media followed by the 3D-inversion of airborne synthesized data. The geoelectrical models chosen for investigation are taken as typical of this class of airborne EM surveys: the rugged topography and the conductive inhomogeneous top layer, which overlaps the low-resistive layer containing target conductive bodies. It is shown that, if the variations of the top layer thickness do not exceed $30 \ldots 35 \mathrm{~m}$ in performing $3 \mathrm{D}$-inversion, as a minimum, at its first stage, the top layer can be recovered as equivalent with constant (but recovered) thickness, i.e. when the top layer is parameterized in the inverse problem, in the vector of the unknowns we can include only lateral borders of 3D-inhomogeneities, their conductivity, and layer thickness described by one parameter. It is also shown that, if, in the medium under study, the variations of the top layer thickness are more significant, its bottom border should be recovered in more detail, because otherwise the target objects located in the second layer with the responses of about $15 \ldots 20 \%$ of the measured signals can be missed, while, in the case of recovering the top layer parameters more accurately, these target objects can be discovered quite confidently.
\end{abstract}

Keywords: airborne electromagnetic survey, numerical 3D-modeling, geometric 3D-inversion, electromagnetic field, sounding in time domain, topography, equivalent solutions, inverse problems

${ }^{*}$ Received 09 March 2018.

The study was performed with financial support from the President grant no. MD-3516.2017.5 and the President grant no. MK-5010.2018.9. 


\section{INTRODUCTION}

Nowadays, the airborne electrical survey is widely used for geophysical investigations of large remote areas with the purpose of finding the solid mineral deposits and ground waters, performing engineering surveys, etc. The sounding is carried out with the use of airborne electromagnetic systems in which, as a rule, the electromagnetic field source and receiver are moved using the helicopter, and electromagnetic responses are studied in time domain after turning-off the current in the source $[1,2,6]$. The important place in implementing these technologies is taken by data processing, the quality of which, in fact, determines the effectiveness of airborne electromagnetic investigation as a whole.

However, the practice of airborne electromagnetic survey is that the investigated media, besides target objects (as a rule, local conductive bodies of small sizes, including Kimberlite pipes, subvertical objects, which are typical of ore deposits, etc.), contain the geological objects-noises in the top layers overlapping the layers with target objects. These media are also characterized by elevations in the Earth surface relief and depths of subhorizontal borders between the layers of a geological medium. The response of target objects in the measured signal is mixed with the response of objects-noises. This has led to meaninglessness of applications of widely used local 1D-inversions and to skipping target objects and/or finding erroneous ones.

In that regard, many scientific works in this direction are related with improving the numerical methods and corresponding software implementing 3-D inversion of airborne electromagnetic data $[5,6,10,11,14,18,19]$, which are based on highly accurate multidimensional numerical modeling and solving multidimensional inverse problems (3D-inversions).

The most common approaches to performing 3D-inversions are the approaches based on dividing the investigated volume into small cells in which the values of conductivity are determined (for example, $[5,6,10,18,19]$ ). However, the workability of these approaches is, as a rule, suggested with the use of synthetic data obtained for quite simple geoelectrical 3D-models that cannot guarantee the obtaining of acceptable results in practice when the geoelectrical structure of the investigated medium is more complex. Moreover, these approaches require a very fine tuning and highly depend on the user qualification that complicates the processing of big arrays of practical data.

Therefore, nowadays the alternative approach to 3D-inversions a geometric $3 \mathrm{D}$-inversion (it is named also as "parametric" $[7,8]$ or "block inversion" $[3,16]$ ) is developed. This approach is based on joint recovery of the shape of structural parts of the geoelectrical model and their physical properties [9, 11, 12].

One of the main questions in developing the geometric 3D-inversion algorithm is parameterization of the unknown geoelectrical model of a geological medium. On the one hand, the number of unknown parameters should be quite sufficient for representing the shape of all structural geoelectrical model parts, which give a significant response in the measured signal, but on the other hand, it is important to minimize the number of these parameters with a purpose, firstly, to reduce the computational costs, and secondly, to reduce the number of equivalent solutions and provide more stable convergence of solving the nonlinear inverse problem. 
In this paper, using the geometric 3D-inversion $[9,11,12]$ algorithm, we presented the results of investigation concerning possible equivalent solutions in processing the data of airborne electrical survey. These results make it possible to formulate recommendations to constructing the initial models (parameterization) of a geological medium for performing the geometric 3D-inversions.

\section{PROBLEM DEFINITION}

A common cause of finding the equivalent solutions of inverse electrical survey problems is the fact that the change of conductivity and corresponding change of the thickness of the geoelectrical model structural parts (the subhorizontal borders of geological layers and 3D-inhomogeneities included in them) give close responses in the measured signal.

Note that in ground and marine technologies of electrical survey, which are applied in oil and gas prospecting, the subhorizontal borders of a geological medium are quite often defined using the seismic data.

However, as a rule, seismic prospecting is not included into the series of works relating to airborne electrical survey, therefore, the subhorizontal borders of a geological medium are unknown as well as the conductivity distribution and lateral borders of 3D-inhomogeneities. At the same time, the geological media in which the airborne electrical survey is carried out can be considered as threelayered media (that follows from their responses in measured signals). In these situations, the top layer is conductive and contains lateral 3D-inhomogeneities, which are, in fact, the preventing factors (the so-called geological objects-noises). The second layer is, as a rule, quite homogeneous, low-conductive and contains target objects. The third layer can also be inhomogeneous, but it has a depth such that the signals registered in the receivers are influenced either by overall layer conductivity or sufficiently big geoelectrical inhomogeneities in this layer.

Therefore, in spite of the fact that the target is the second layer, it is almost impossible to recover its structure (i.e. location, shape, and conductivity of target objects) without recovering the structure of the top layer (true or even its equivalent). In this relation, the following question appears: is it sufficient (for determining the responses of target objects in the measured signals) to conduct a search for the lateral distribution of conductivity in the top layer of constant (equivalent) thickness, thereby significant reducing the number of unknown parameters (and, correspondingly, run time of 3D-inversion), or is it necessary to search simultaneously for the conductivity distribution in the top layer and its thickness changing on the area.

We perform these studies in the following way. Using the 3D-modeling of airborne electrical survey, we obtain "experimental" (synthetic) data for a typical (to a sufficiently wide class of the airborne electrical survey problems) geoelectrical model the top layer of which has a varied thickness. Then, using the geometric 3D-inversion of these "experimental" data, we search for an equivalent (in the sense of response in the measured signal) model of conductivity distribution in the top layer with a constant depth. Obtaining the equivalent model as a result of the inversion allows us to recommend the use only lateral borders of 3D-inhomogeneities, their conductivity, and layer thickness described by a single parameter for parameterization of the top layer in the inversion of the practical data. 


\section{MATHEMATICAL MODELS}

\subsection{FORWARD PROBLEM SOLUTION}

In order to calculate the electromagnetic field induced and received by the induction loops of the airborne system in time domain, we use the vector finite element method with edge basis functions on 3D-hexahedral non-conforming meshes with "hanging" nodes $[4,5,17,20,22,23]$. The description of the electromagnetic field requires the use of the vector-potential $\overrightarrow{\mathbf{A}}$, which relates with the electrical field and magnetic induction by the ratios $\overrightarrow{\mathbf{E}}=-\frac{\partial \overrightarrow{\mathbf{A}}}{\partial t}$ and $\overrightarrow{\mathbf{B}}=\nabla \times \overrightarrow{\mathbf{A}}$. In its turn, the functions $\overrightarrow{\mathbf{A}}, \overrightarrow{\mathbf{E}}$, and $\overrightarrow{\mathbf{B}}$ appear as $\overrightarrow{\mathbf{A}}=\overrightarrow{\mathbf{A}}^{p}+\overrightarrow{\mathbf{A}}^{s}, \overrightarrow{\mathbf{E}}=\overrightarrow{\mathbf{E}}^{p}+\overrightarrow{\mathbf{E}}^{s}$, and $\overrightarrow{\mathbf{B}}=\overrightarrow{\mathbf{B}}^{p}+\overrightarrow{\mathbf{B}}^{s}$, respectively, where the functions $\overrightarrow{\mathbf{A}}^{p}, \overrightarrow{\mathbf{E}}^{p}$, and $\overrightarrow{\mathbf{B}}^{p}$ describe the field in a homogeneous non-conductive medium and can be calculated either analytically or numerically by means of solution of the corresponding axisymmetrical problem (for example, [13]). The function $\overrightarrow{\mathbf{E}}^{p}$ is fully determined by changing the current in the transmitter and calculated as $-\frac{\partial \overrightarrow{\mathbf{A}}^{p}}{\partial t}$.

The electromagnetic field in three dimensional computational domain $\Omega$ can be found from the solution of vector differential equation

$$
\frac{1}{\mu_{0}} \nabla \times \nabla \times \overrightarrow{\mathbf{A}}^{s}+\sigma \frac{\partial \overrightarrow{\mathbf{A}}^{s}}{\partial t}=\sigma \overrightarrow{\mathbf{E}}^{p},
$$

where the vector-potential $\overrightarrow{\mathbf{A}}^{s}$ relates with the three dimensional components of electric and magnetic fields $\overrightarrow{\mathbf{E}}^{s}$ and $\overrightarrow{\mathbf{B}}^{s}$ by the ratios $\overrightarrow{\mathbf{E}}^{s}=-\frac{\partial \overrightarrow{\mathbf{A}}^{s}}{\partial t}$ and $\overrightarrow{\mathbf{B}}^{s}=\nabla \times \overrightarrow{\mathbf{A}}^{s}$. On the remote boundaries $\partial \Omega$ of three dimensional computational domain $\Omega$, the zero tangential components of $\overrightarrow{\mathbf{A}}^{s}$ are set:

$$
\overrightarrow{\mathbf{A}}^{s} \times\left.\overrightarrow{\mathbf{n}}\right|_{\partial \Omega}=\overrightarrow{\mathbf{0}},
$$

where $\overrightarrow{\mathbf{n}}$ is the vector normal to the boundary $\partial \Omega$.

The equivalent variational formulation for Eq. (1) has a form:

$$
\int_{\Omega} \frac{1}{\mu_{0}}\left(\nabla \times \overrightarrow{\mathbf{A}}^{s}\right) \cdot(\nabla \times \overrightarrow{\mathbf{\Psi}}) d \Omega+\int_{\Omega} \sigma \frac{\partial \overrightarrow{\mathbf{A}}^{s}}{\partial t} \overrightarrow{\mathbf{\Psi}} d \Omega=\int_{\Omega} \sigma \overrightarrow{\mathbf{E}}^{p} \cdot \overrightarrow{\mathbf{\Psi}} d \Omega,
$$

where $\overrightarrow{\mathbf{\Psi}}(x, y, z)$ is a test vector function.

Time discretization of $\frac{\partial \overrightarrow{\mathbf{A}}^{s}}{\partial t}$ is performed with the use of three-point implicit scheme $[20,22]$.

Finite element approximation of variational Eq. (3) is performed on the hexahedral non-conforming meshes. The algorithm of these meshes generation, the methods 
of calculating the local matrices as well as the algorithm of constructing the conforming basis on the non-conforming meshes are presented in papers [17, 22].

The reduction of computational costs with keeping the accuracy of numerical solutions is achieved due to grouping the sub-problems each of which corresponds to one position of the source in space and one time instance, and using the direct solvers (for example, PARDISO [15]) of the finite element system of linear algebraic equations (SLAE).

The groups of sub-problems are formed such that the SLAE matrix, which is obtained as a result of space and time discretization, is the same for all subproblems. This allows us to perform the matrix factorization only once for all subproblems of a group, and in order to obtain the solution of each sub-problem, the solution of two SLAE with triangle matrices needs to be carried out. For grouping in space, the finite element mesh is generated such that to provide the required solution accuracy for all source positions in a group (see, for example, the papers $[5$, $10,17,20])$.

\subsection{INVERSE PROBLEM SOLUTION}

The inverse problem solution is based on the use of the geometric 3-D inversion $[9,11,12,14,21]$.

Taking into account the specifics of the airborne survey, we use the geoelectrical model parameterization where it is represented by a set of subhorizontal layers each of which is divided into the block rows elongated essentially along the flight lines. For example, if we assume that the flight lines are oriented (mainly) along the $x$-coordinate, that unknown parameters can be $x$-coordinates of borders of blocks, $y$-coordinates of the block rows as well as values of conductivity inside each block.

The components of the vector of parameters, which describe the geoelectrical model, are found by minimizing the following functional

$$
\Phi^{\alpha}(\mathbf{b})=\sum_{i=1}^{K} \sum_{l=1}^{L}\left(\omega_{i l} \delta \varepsilon_{i l}(\mathbf{b})\right)^{2}+\sum_{m=1}^{M} \alpha_{m}\left(b_{m}-\bar{b}_{m}\right)^{2} \rightarrow \min _{b_{m}},
$$

where $K$ is the number of transmitter-receiver positions, $L$ is the number of time channels, $\delta \varepsilon_{i l}(\mathbf{b})$ is the difference of theoretical $\varepsilon_{i l}$ and measured $\tilde{\varepsilon}_{i l}$ values of signals in the $i$-th receiver at the $l$-th time channel, $M$ is the number of unknown parameters, $\bar{b}_{m}$ is the value of the $m$-th parameter at previous iteration.

The values of the weight functions $\omega_{i l}$ are chosen equal to $1 / \tilde{\varepsilon}_{i l}$. If $\tilde{\varepsilon}_{i l}$ is lower than some tolerable limit $\bar{\varepsilon}_{i l}$ defined by the level of a measurement error for each specific airborne system, then the value of the weight function is taken equal to $1 / \bar{\varepsilon}_{i l}$. The regularization parameters $\alpha_{m}$ are chosen adaptively during the inverse problem solution. The regularization component with parameters $\alpha_{m}$ provides the search for the parameter within tolerable limits of values thereby keeping the geometry of the structural part of the geological model and providing physical values of their conductivity. 
Representing the values $\delta \varepsilon_{i l}(\mathbf{b})$ as two summands of Taylor series in the vicinity of the parameter values $\overline{\mathbf{b}}$ at the previous iteration, we obtain

$$
\delta \varepsilon_{i l}(\mathbf{b}) \approx \delta \varepsilon_{i l}(\overline{\mathbf{b}})+\left.\sum_{m=1}^{M} \frac{\partial\left(\delta \varepsilon_{i l}\right)}{\partial b_{m}}\right|_{\mathbf{b}=\overline{\mathbf{b}}} \Delta b_{m},
$$

where $\Delta b_{m}=b_{m}-\bar{b}_{m}$. In order to calculate the derivatives $\frac{\partial\left(\delta \varepsilon_{i l}\right)}{\partial b_{m}}$, we solve the following vector differential equation:

$$
\frac{1}{\mu_{0}} \nabla \times \nabla \times \overrightarrow{\mathbf{A}}^{s \mid m}+\sigma^{m} \frac{\partial \overrightarrow{\mathbf{A}}^{s \mid m}}{\partial t}=\left(\sigma^{m}-\sigma\right) \overrightarrow{\mathbf{E}},
$$

for the increment $\partial b_{m}$ of each component of the vector of parameters.

In Eq. (6), the field $\overrightarrow{\mathbf{E}}$ is the result of the forward problem solution described in Section 2.1 for values of parameters $b_{m}=\bar{b}_{m}$ obtained at the previous iteration and defining the current distribution $\sigma(x, y, z)$. The value of the function $\sigma^{m}(x, y, z)$ differ from the values of the function $\sigma(x, y, z)$ only in the places where the conductivity is changed due to the increment of the parameter $b_{m}$ in $\partial b_{m}$. The variational formulation and finite element approximation for Eq. (6) are constructed as well as for Eq. (1).

Using the values $\overrightarrow{\mathbf{A}}^{s \mid m}(x, y, z, t)$, we define the values of the derivatives of errors of signals in receivers $\frac{\partial\left(\delta \varepsilon_{i l}\right)}{\partial b_{m}}=\frac{\partial \varepsilon_{i l}}{\partial b_{m}}$ (i. e. as $-\frac{\partial\left(\nabla \times \overrightarrow{\mathbf{A}}^{s \mid m}\right)}{\partial t} \frac{k_{r}}{\partial b_{m}}$, where $k_{r}$ is the receiver moment).

Substituting ratio (5) in (4), we obtain

$$
\begin{gathered}
\tilde{\Phi}^{\alpha}(\mathbf{b})=\sum_{i=1}^{K} \sum_{l=1}^{L}\left(\omega_{i l}\left(\delta \varepsilon_{i l}(\overline{\mathbf{b}})+\left.\sum_{m=1}^{M} \frac{\partial\left(\delta \varepsilon_{i l}\right)}{\partial b_{m}}\right|_{\mathbf{b}=\overline{\mathbf{b}}} \Delta b_{m}\right)\right)^{2}+ \\
+\sum_{m=1}^{M} \alpha_{m}\left(\Delta b_{m}\right)^{2} \rightarrow \min _{\Delta b_{m}}
\end{gathered}
$$

The minimization of (7) results in SLAE in the form

$$
(\mathbf{G}+\alpha) \Delta \mathbf{b}=\mathbf{f},
$$

where the components of the matrix $\mathbf{G}$ and right hand side vector $\mathbf{f}$ are calculated with the use of the ratios

$$
G_{p s}=\sum_{i=1}^{K} \sum_{l=1}^{L} \omega_{i l}^{2} \frac{\partial\left(\delta \varepsilon_{i l}\right)}{\partial b_{p}} \frac{\partial\left(\delta \varepsilon_{i l}\right)}{\partial b_{s}}, f_{p}=-\sum_{i=1}^{K} \sum_{l=1}^{L} \omega_{i l}^{2} \delta \varepsilon_{i l}(\mathbf{b}) \frac{\partial\left(\delta \varepsilon_{i l}\right)}{\partial b_{p}}, p, s=1 \ldots M .
$$


In SLAE (8), the matrix $\alpha$ is a diagonal matrix with elements $\alpha_{m}$ on the main diagonal. The algorithm of the adaptive choice of coefficients $\alpha_{m}$ at each iteration of the nonlinear inversion is presented in [9].

\subsection{PRINCIPALS OF PARALLEL IMPLEMENTATION}

We propose the parallel implementation of the inverse problem solution using the multicore PC connected by the local net (further, we call these PCs as computational nodes).

As mentioned above, all positions of the airborne system are divided into groups which contain up to 100 positions depending on the distance between the adjacent positions on the flight lines and the distance between them. The calculation for each group is carried out on a computational node.

In order to allocate the problems to a computational node, we have developed a control program, which sends data to computational nodes, controls the obtaining of results and the connection with the corresponding computational node. If any computational node is disconnected for a long time, or the numerical procedure is aborted due to any reason (for example, turning-off the PC or starting some other task requiring high computational resources), the control program restarts the calculation for the corresponding group on the other computational node. Thus, the developed control program provides fault tolerance of the system for parallelizing the inverse problem solution.

At each computational node simultaneously with the forward problem solution for the geoelectrical model, which is obtained at the current iteration of nonlinear inversion, the fields of the impact of geoelectrical model parameters are calculated for the next iteration of nonlinear inversion because their calculation requires the values of the electric field density in the volume of the recovered medium. The calculation of the fields of the impact of geoelectrical model parameters is carried out with parallelization on the cores of the corresponding computational node.

The developed approaches to the solution of forward and inverse problems in combination with the control program enable us to use heterogeneous computational systems consisting of the independent standard PCs which are easily replaced even during the inversion fulfillment.

\section{NUMERICAL EXPERIMENTS}

In order to perform the numerical experiments, we use three geoelectrical models. The first two models represent the layered medium with the topography in which the elevations reach $60 \mathrm{~m}$ for the lateral displacement of $600 \mathrm{~m}$. In these models the layer thickness varies from $49 \mathrm{~m}$ to $12 \mathrm{~m}$, and, in the third model, this thickness varies from $64 \mathrm{~m}$ to $3 \mathrm{~m}$. The first geoelectrical model does not contain lateral 3D-inhomogeneities, and the second and third models include two quite large parts with 3D-inhomogeneities of low resistivity.

Using the numerical schemes of 3D-modeling, which are described in section 2.1 , for these three geoelectrical models, the airborne electrical survey data have been synthesized along 10 flight lines (profiles). The total number of airborne system positions on all flight lines is 1311 . Further, we call these data "practical". For each airborne system position, the data are synthesized at 23 time channels in the time range of $1 \mu$ s to $1 \mathrm{~ms}$. 
Fig. 1 shows the sections of the geoelectrical model 1 along four flight lines (flight lines are shown by light points and denoted as P1...P10). We can see the changes of the top layer thickness both along and across the flight lines.

For the data, which are synthesized for model 1, the 3D-inversion is performed. The unknown parameters are the top layer thickness in the condition that it is constant and the corresponding conductivity distribution, which suggests the equivalence of inhomogeneous layer of the constant thickness and true homogeneous layer with varying thickness. In the top layer of the initial (for 3D-inversion) model, the block structure containing $7 \times 7$ blocks $(7$ rows with 7 blocks in each row) is set. The vector of unknown parameters includes the $x$-coordinates of the blocks (the $x$-coordinates of the adjacent blocks are set by a single parameter), $y$ coordinates of the block rows ( $y$-coordinates of the adjacent rows are also set by a single parameter), the conductivities inside each block, and layer thickness. The total number of parameters, which are used for recovering the geoelectrical model, is 117 .

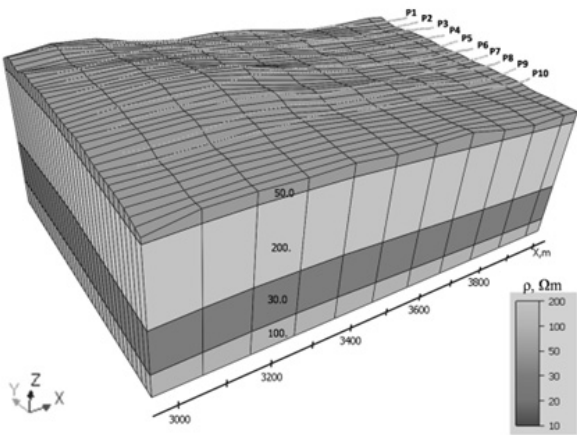

$a$

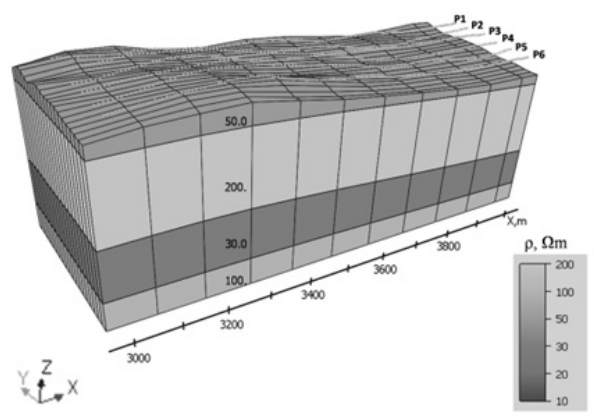

c

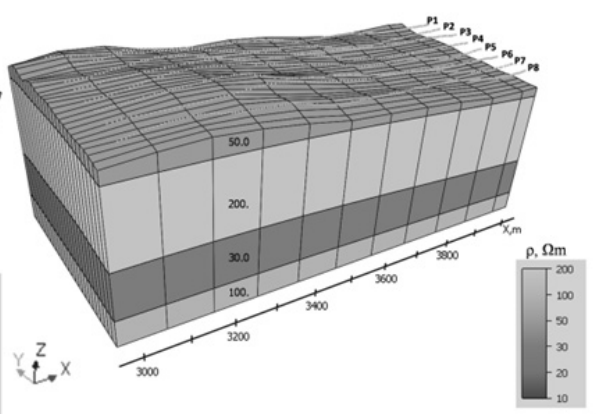

$b$

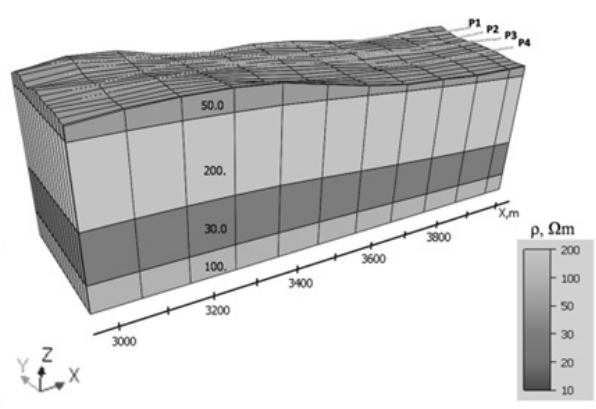

$d$

Fig. 1. The section of the geoelectrical model 1 along flight lines P10 (a), P8 (b), P6 (c), and $\mathrm{P} 4(d)$

During the 3D-inversion six iterations were performed, after that the value of the residual functional

$$
\Phi(\mathbf{b})=\sum_{i=1}^{K} \sum_{l=1}^{L}\left(\omega_{i l} \delta \varepsilon_{i l}(\mathbf{b})\right)^{2},
$$


became equal to 0.0198 , and the values of the parameters did not significantly change (for the initial model, the residual functional is equal to 0.191). Fig. 2 shows the geoelectrical model obtained after the sixth iteration. The comparison of Figs. 1 and 2 shows that, in general, the obtained value of layer resistivity is about $50 \Omega \mathrm{m}$ : most of the blocks, which are deformed as a result of 3D-inversion, have the resistivity in the range of 45 to $65 \Omega \mathrm{m}$ which corresponds to the layer resistivity in the "true" model. As expected, the most distortion of the conductivity is seen for the blocks which are located in the vicinities of the maximal thickening and thinning of the layer in the "true" model. In these places of the equivalent model, which is obtained as a result of 3D-inversion with the constant thickness of the layer (this thickness has been obtained equal to $32.34 \mathrm{~m}$ ), the values of the block resistivity reach 30 and $150 \Omega \mathrm{m}$, respectively.

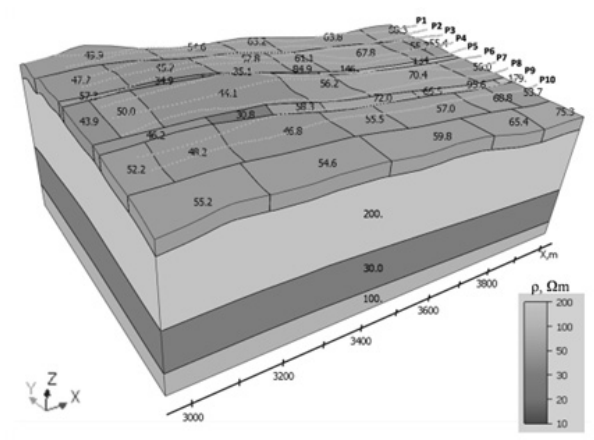

Fig. 2. The geoelectrical model obtained after the sixth iteration of 3D-inversion

The degree of the equivalence of the geoelectrical model with the constant layer thickness, which is obtained as a result of 3D-inversion, and the "true" model can be estimated using the curves of signals along the flight lines at different time channels. Figs. 3a-c show these curves obtained for the recovered model (further, we call the corresponding curves theoretical) and for the "true" model ("practical" data) at five characteristic time channels. Besides, in these figures, light solid lines show the curves which are calculated for the model with the constant thickness of the top curved (according to the relief) layer equal to $32.34 \mathrm{~m}$ (i.e. with the thickness taken from the recovered model) and with the top layer resistivity taken from the "true" model.

As is seen from the results shown in Fig. 3, the deviations of the "practical" and theoretical data do not exceed 5 per cent while the deviations of signals, which are calculated for the models with varied and constant thickness of the curved top layer, are significant. This is say to that, for processing practical airborne electrical survey data, these models are equivalent.

Fig. 4 shows the sections of the geoelectrical model 2 the top layer of which (unlike model 1) includes 3D-inhomogeneities with lowered resistivity. The recovered model is shown in Fig. 4. As is seen from the results, the deformed blocks of the recovered model, which are displaced to subdomains corresponding to $3 \mathrm{D}$-inhomogeneities locations in the "true" model 2, have lower (relative to the layer) resistivity. However, the resistivity of the blocks, which are positioned in the zone of the layer thickening in the "true" model, has been obtained lower than in the 
"true" model (the group of inhomogeneities located on the left part near flight line P4). The resistivity of the blocks, which are positioned in the zone of the layer thinning, has been obtained somewhat high (the group of inhomogeneities located on the right part near flight line P4). During the 3D-inversion nine iterations were performed, after that the value of the residual functional (10) became equal to 0.0347 (for the initial model, this value is equal to 0.221 ), and the parameters of the model at last two iterations did not change significantly. The thickness of the equivalent top layer has been obtained equal to $31.76 \mathrm{~m}$.

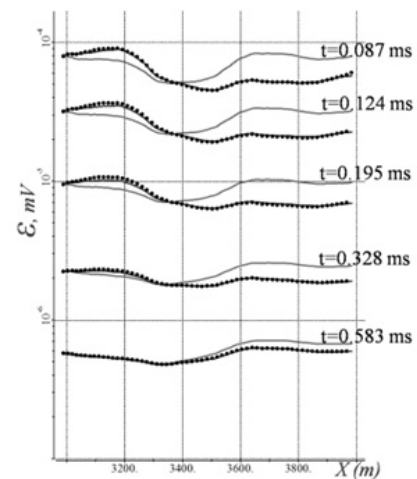

$a$

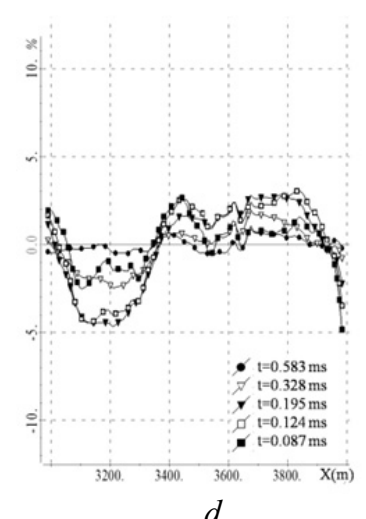

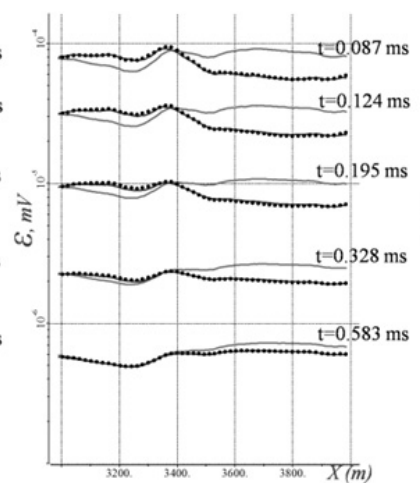

$b$

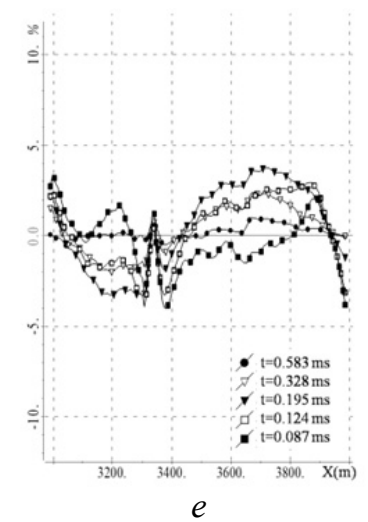

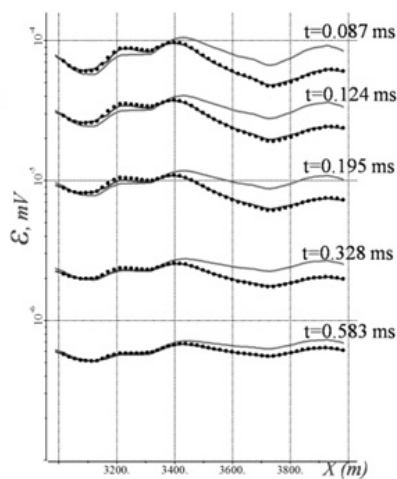

c

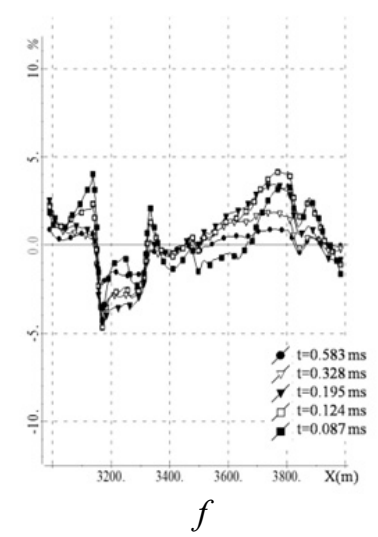

Fig. 3. The theoretical data (dark solid lines) for the model obtained at the sixth iteration, the "practical" data (black points), and the data calculated for the model with the constant thickness of the top curved (according to relief) layer equal to $32.34 \mathrm{~m}$ and with the top layer resistivity taken from the "true" model (light solid lines). The data are shown at five time channels along flight lines P4, P6, and P8 (Figs. $a, b, c$, respectively). The deviations of theoretical data (the recovered model) and "practical" data (the "true" model) at five time channels along flight lines P4, P6, and P8 (Figs. $d, e, f$, respectively)

Fig. 6 shows the curves, which are obtained for the recovered and "true" models, and their deviations. It can be noted, that, in this case, the deviations increases, especially at early times (the time channel $t=0.087 \mathrm{~ms}$ ) and reach $7 \ldots 8 \%$. Nevertheless, for processing the practical airborne data, these models can be recognized as equivalent as well as in the case of model 1. 


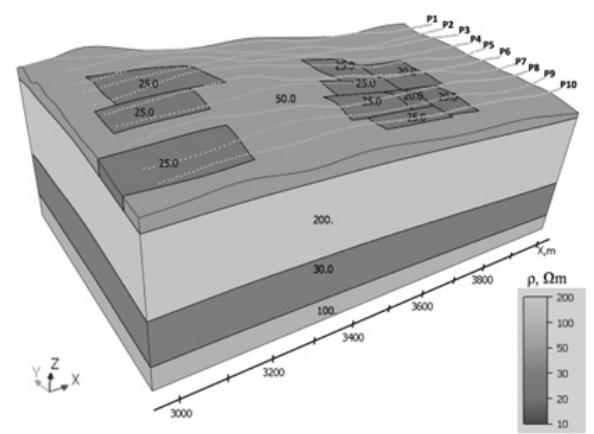

$a$

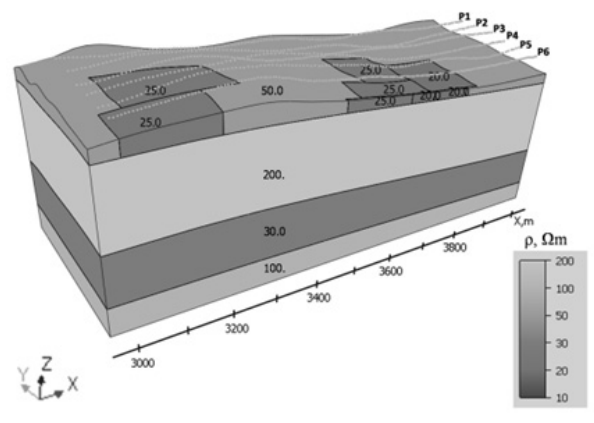

c

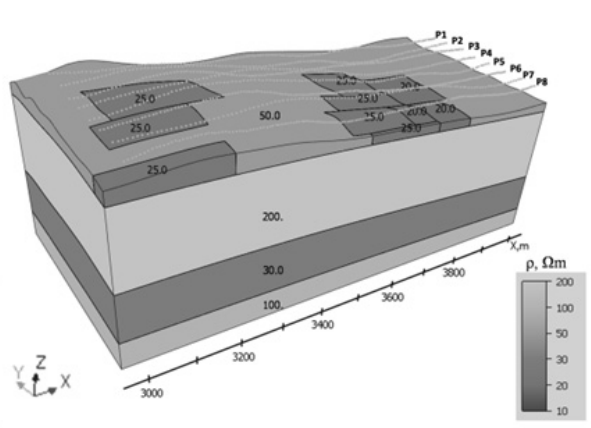

$b$

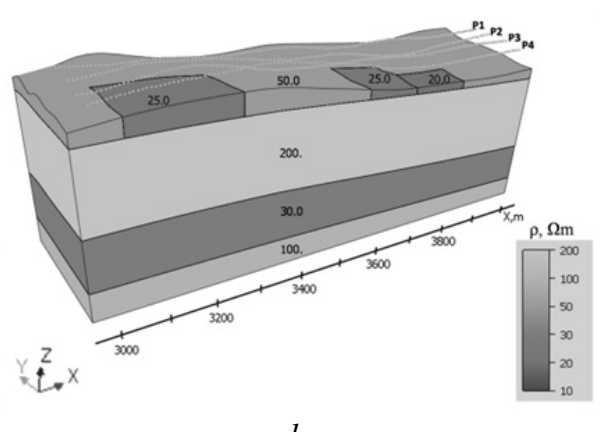

$d$

Fig. 4. The sections of the geoelectrical model 2 along flight lines P10 (a), P8 (b), P6 (c), and P4 (d)

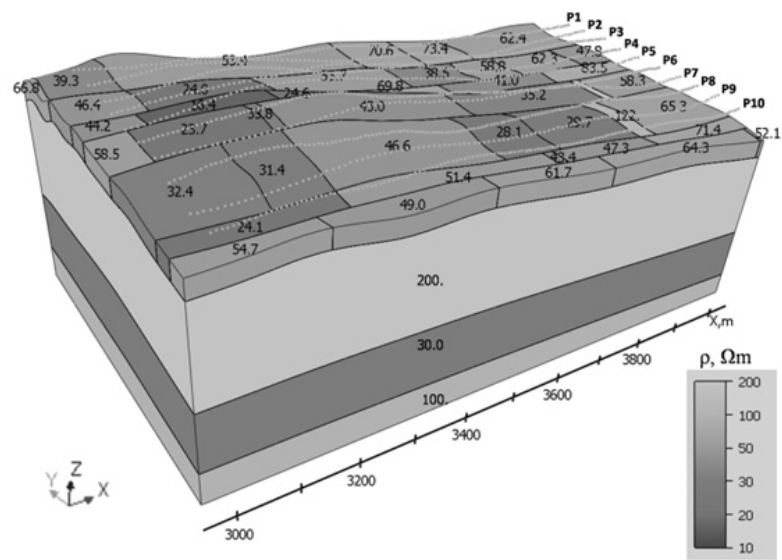

Fig. 5. The geoelectrical model obtained after the ninth iteration of $3 \mathrm{D}$-inversion

Fig. 7 shows the sections of the geoelectrical model 3 the top layer of which (as well as in model 2) contains lateral 3D-inhomogeneities with lower resistivity, but in this model, the changes of the top layer thickness reach about $60 \mathrm{~m}$, the recovered model is shown in Fig. 8. Fig. 9 shows the curves, which are obtained for the recovered and "true" models, and their deviations. 

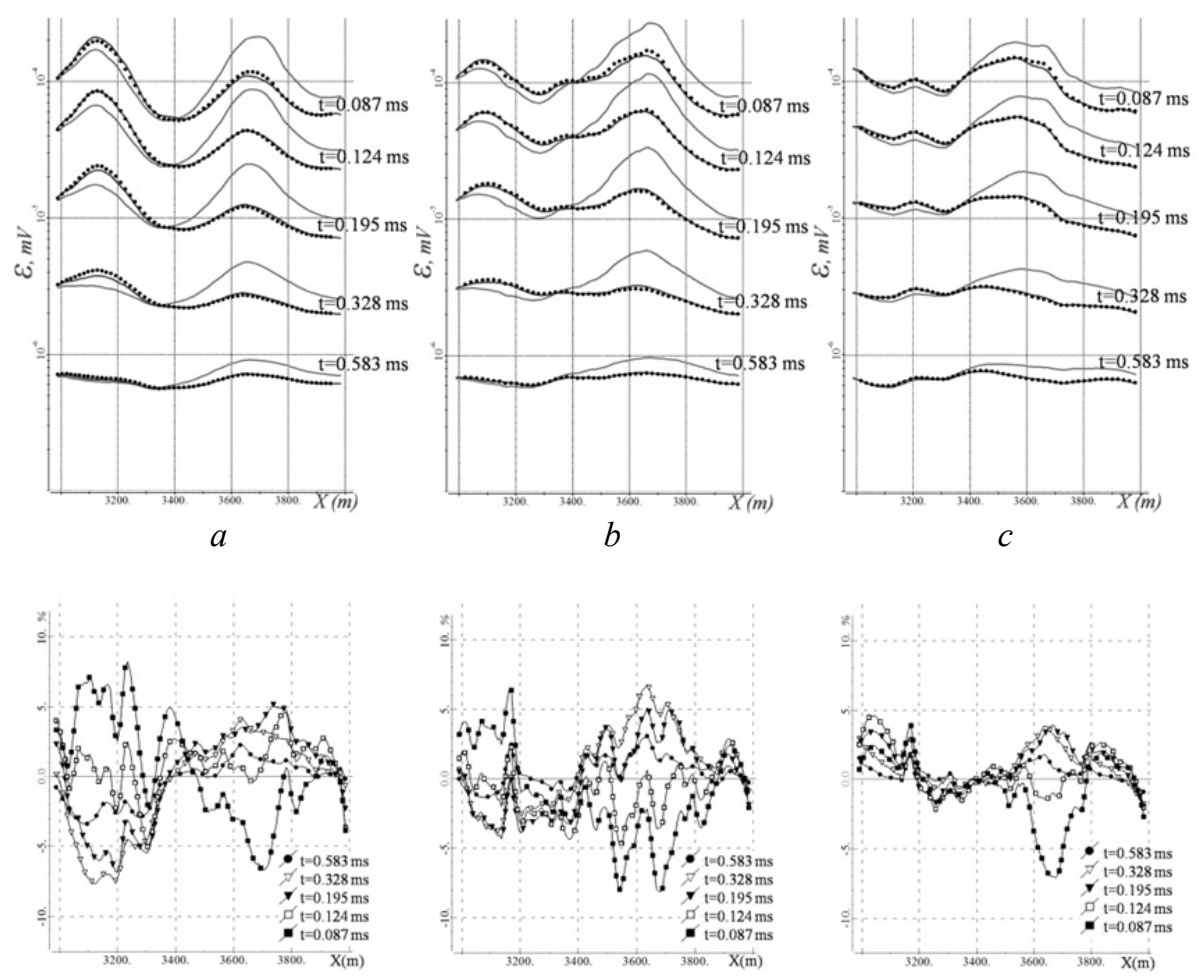

$d$

$e$

$f$

Fig. 6. The theoretical data (dark solid lines) for the model obtained at the ninth iteration, the "practical" data (black points), and the data calculated for the model with the constant thickness of the top curved (according to the relief) layer equal to 31.76 $\mathrm{m}$ and with inhomogeneities taken from the "true" model 2 (light solid lines). The data are shown at five time channels along flight lines P4, P6, and P8 (Figs. $a, b, c$, respectively). The deviations of theoretical data (the recovered model) and "practical" data (the "true" model) at five time channels along flight lines P4, P6, and P8

(Figs. $d, e, f$, respectively)

During the 3D-inversion eight iterations were performed, after that the value of the residual functional (10) became equal to 0.0466 (for the initial model, this value is equal to 0.354 ), and the parameters of the model at last two iterations did not change significantly. The thickness of the top layer was obtained equal to $45.33 \mathrm{~m}$.

As is seen from the results, the deviations of the curves, which are obtained for the recovered and "true" models, reach $10 \ldots 12$ per cent, and the recovered model cannot be admitted as equivalent because, in this case, we can skip the target objects, which are located in the second layer and have the responses about $15 \ldots 20$ per cent in the measured signals, while these objects can be reliably discovered if the top layer is recovered more accurately. 


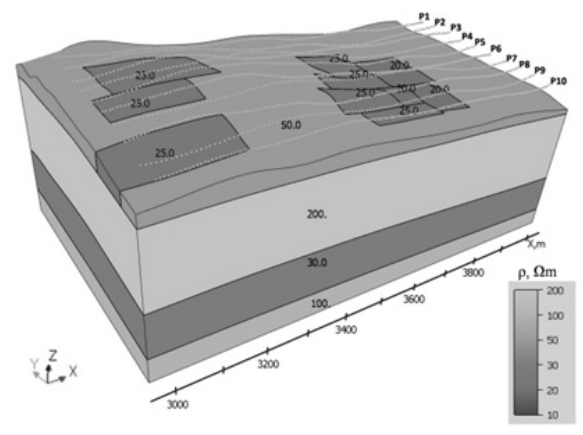

$a$

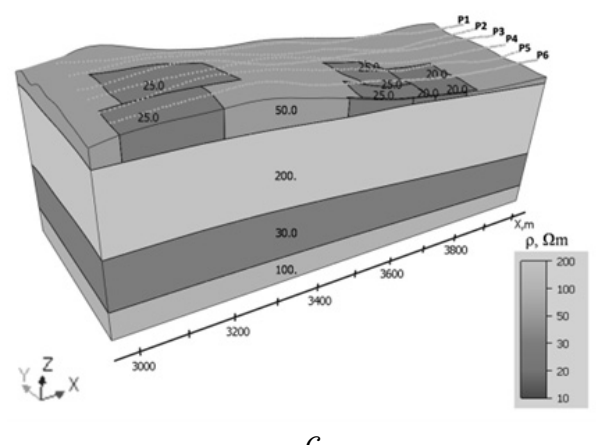

$c$
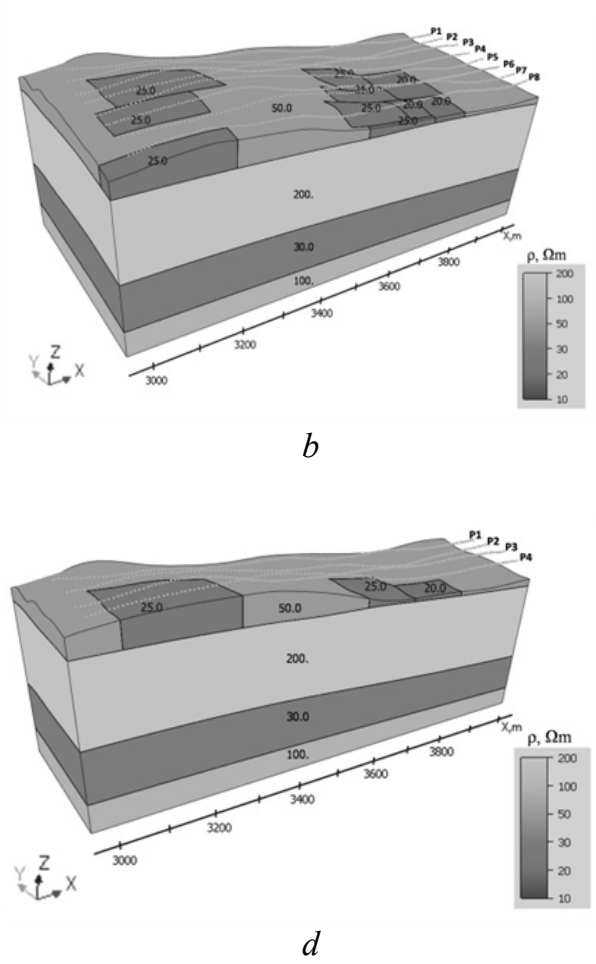

Fig. 7. The sections of the geoelectrical model 3 along flight lines P10 (a), P8 (b), P6 (c), and P4 (d)

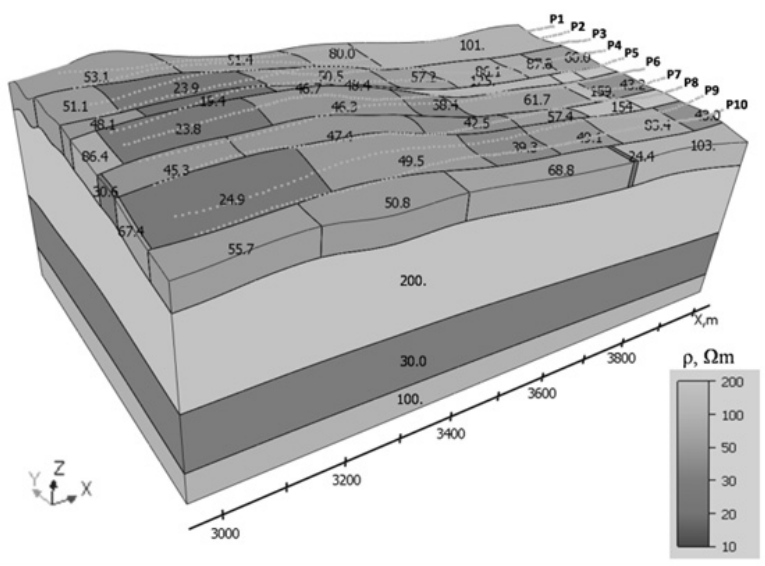

Fig. 8. The geoelectrical model obtained after the eight iteration of the 3D-inversion 


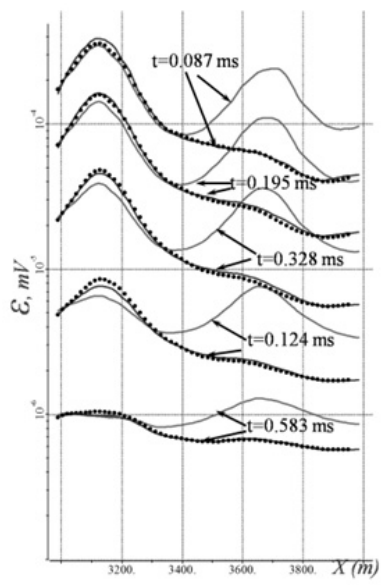

$a$

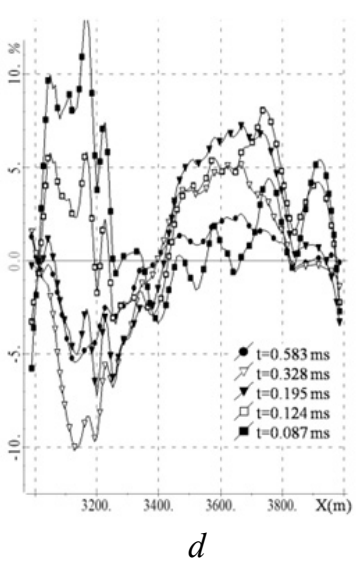

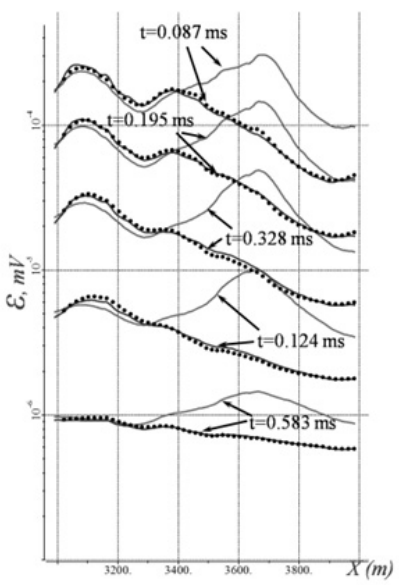

$b$

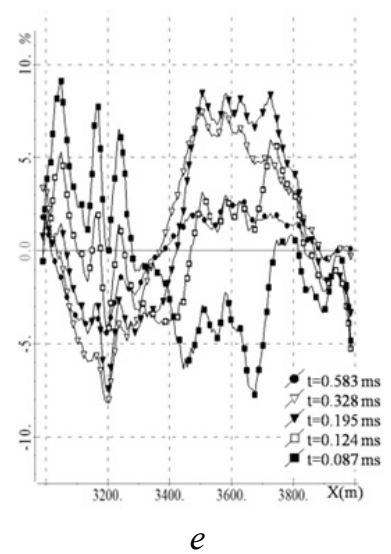

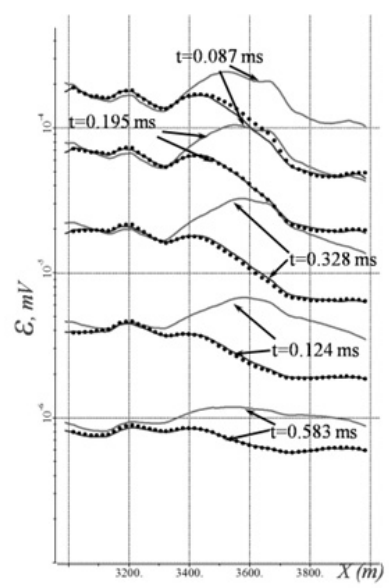

c

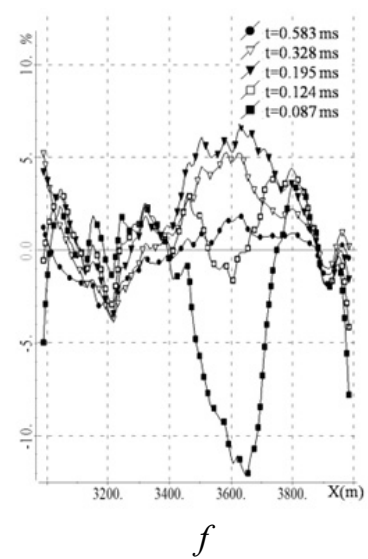

Fig. 9. The theoretical data (dark solid lines) for the model obtained at the eighth iteration, the "practical" data (black points), and the data calculated for the model with the constant thickness of the top curved (according to relief) layer equal to $45.33 \mathrm{~m}$ and with inhomogeneities taken from the "true" model 3 (light solid lines). The data are shown at five time channels along flight lines $\mathrm{P} 4, \mathrm{P} 6$, and $\mathrm{P} 8$ (Figs. $a, b, c$, respectively). The deviations of theoretical data (the recovered model) and "practical" data (the "true" model) at five time channels along flight lines P4, P6, and P8 (Figs. $d, e, f$, respectively)

\section{CONCLUSIONS}

On the basis of the 3D-modeling results, we can make conclusions about the parameterization of geoelectrical models for performing 3D-inversion of the airborne data in the conditions typical of the airborne electrical survey: in geological media with the topography and conductive laterally inhomogeneous top layer (which is, actually, the noise factor) overlapping the low conductive layer with target conductive bodies. 
In the case, if the changes of the top layer thickness do not exceed $30 \ldots 35 \mathrm{~m}$, at least at the first stage of 3D-inversion, it can be found as equivalent with a constant (but recovered) thickness almost without losing the quality of detecting the target objects. Thus, for parameterization of the top layer, the vector of unknown parameters can include only the lateral borders of 3D-inhomogeneities, their conductivities, and layer thickness represented by a single parameter.

If the changes of the top layer thickness are more significant in the investigated area, the shape of the bottom border of this layer should be determined during the 3D-inversion. In this case, it can be parameterized with the use of increments of the $z$-coordinates of some control points of the spline representing this border thereby more reliably discovering the target objects in the second layer.

\section{REFERENCES}

1. Abd Allah S., Mogi T., Ito H., Jomori A., Yuuki Y., Fomenko E., Kiho K., Kaieda H., Suzuki K., Tsukuda K. Three-dimensional resistivity characterization of a coastal area: application of grounded electrical-source airborne transient electromagnetic (GREATEM) survey data from Kujukuri Beach, Japan. Journal of Applied Geophysics, 2013, vol. 99, pp. 1-11.

2. Andersen K.K., Kirkegaard C., Foged N., Christiansen A.V., Auken E. Artificial neural networks for removal of couplings in airborne transient electromagnetic data. Geophysical Prospecting, 2016, vol. 64, no. 3, pp. 741-752.

3. Dehiya R.S.A., Gupta P.K., Israil M. Interpretation of CSEM data using 2D block inversion algorithm. 22nd EM Induction Workshop, Weimar, Germany, 2014.

4. Grayver A.V. Parallel three-dimensional magnetotelluric inversion using adaptive finiteelement method. Part I. Theory and synthetic study. Geophysical Journal International, 2015, vol. 202, no. 1, pp. 584-603.

5. Haber E., Schwarzbach C. Parallel inversion of large-scale airborne time-domain electromagnetic data with multiple OcTree meshes. Inverse Problems, 2014, vol. 30, no. 5.

6. Liu Y., Yin C. 3D inversion for multipulse airborne transient electromagnetic data. Geophysics, 2016, vol. 81, no. 6, pp. E401-E408.

7. McMillan M.S., Schwarzbach C., Haber E., Oldenburg D.W. 3D parametric hybrid inversion of time-domain airborne electromagnetic data. Geophysics, 2015, vol. 80, no. 6, pp. K25-K36.

8. McMillan M.S., Schwarzbach C., Haber E., Oldenburg D.W. Multiple body parametric inversion of frequency- and time-domain airborne electromagnetic. SEG Technical Program Expanded Abstracts, 2016, vol. 35, pp. 846-851.

9. Mogilatov V., Goldman M., Persova M., Soloveichik Y., Koshkina Y., Trubacheva O., Zlobinskiy A. Application of the marine circular electric dipole method in high latitude Arctic regions using drifting ice floes. Journal of Applied Geophysics, 2016, vol. 135, pp. 17-31.

10. Oldenburg D.W., Haber E., Shekhtman R. Three dimensional inversion of multisource time domain electromagnetic data. Geophysics, 2013, vol. 78, no. 1, pp. E47-E57.

11. Persova M.G., Soloveichik Y.G., Koshkina Y.I., Vagin D.V., Trubacheva O.S. Geometrical nonlinear 3D inversion of airborne time domain EM data. Near Surface Geoscience 2016: 1st Conference on Geophysics for Mineral Exploration and Mining, Barcelona, Spain, 2016.

12. Persova M.G., Soloveichik Y.G., Trigubovich G.M., Tokareva M.G. Methods and algorithms for reconstructing three-dimensional distributions of electric conductivity and polarization in the medium by finite-element 3D modeling using the data of electromagnetic sounding. Izvestiya. Physics of the Solid Earth, 2013, vol. 49, no. 3, pp. 329-343.

13. Persova M.G., Soloveichik Y.G., Trigubovich G.M., Vagin D.V., Domnikov P.A. Transient electromagnetic modelling of an isolated wire loop over a conductive medium. Geophysical Prospecting, 2014, vol. 62, no. 5, pp. 1193-1201. 
14. Persova M.G., Soloveichik Y.G., Vagin D.V., Domnikov P.A., Kiselev D.S., Koshkina Y.I., Simon E.I. Multidimensional processing of the airborne EM data in the complex media. Engineering and Mining Geophysics 2018, Kazakhstan, Almaty, 2018.

15. Schenk O., G̈artner K. Solving unsymmetric sparse systems of linear equations with PARDISO. Future Generation Computer Systems, 2004, vol. 20, no. 3, pp. 475-487.

16. Singh A.D.R., Gupta P.K., Israil M. Development of block inversion algorithm and its comparison with cell inversion schemes. 22nd EM Induction Workshop, Weimar, Germany, 2014.

17. Soloveichik Y.G., Persova M.G., Domnikov P.A., Koshkina Y.I., Vagin D.V. Finiteelement solution to multidimensional multisource electromagnetic problems in the frequency domain using non-conforming meshes. Geophysical Journal International, 2018, vol. 212, no. 3, pp. 21592193.

18. Yang D., Oldenburg D.W. Three-dimensional inversion of airborne time-domain electromagnetic data with applications to a porphyry deposit. Geophysics, 2012, vol. 77, no. 2, pp. B23-B34.

19. Yang D., Oldenburg D.W., Haber E. 3-D inversion of airborne electromagnetic data parallelized and accelerated by local mesh and adaptive soundings. Geophysical Journal International, 2014, vol. 196, no. 3, pp. 1492-1507.

20. Persova M.G., $\quad$ Soloveichik Y.G., $\quad$ Vagin D.V., Kiselev D.S., Kondratyev N.V., Koshkina Y.I., Trubacheva O.S. Primenenie nekonformnykh setok s shestigrannymi yacheikami dlya 3D-modelirovaniya tekhnologii aeroelektrorazvedki [Application of non-conforming meshes with hexahedral cells for 3D modelling of airborne electromagnetic technologies]. Doklady Akademii nauk vysshei shkoly Rossiiskoi Federatsii - Proceedings of the Russian higher school Academy of sciences, 2018, no. 1 (38), pp. 64-79.

21. Persova M.G., Trubacheva O.S. O podkhode k resheniyu obratnoi zadachi vyzvannoi polyarizatsii pri vosstanovlenii granits anomal'nykh po polyarizuemosti ob"ektov [On an approach to solving induced polarization inverse problems under recovery of boundaries of an object with anomalous polarizability]. Doklady Akademii nauk vysshei shkoly Rossiiskoi Federatsii - Proceedings of the Russian higher school Academy of sciences, 2015, no. 3 (28), pp. 88-98.

22. Soloveichik Yu.G., Royak M.E., Persova M.G. Metod konechnykh elementov dlya resheniya skalyarnykh $i$ vektornykh zadach [The finite element method for the solution of scalar and vector problems]. Novosibirsk, NSTU Publ., 2007. 896 p.

23. Soloveichik Yu.G., Tokareva M.G., Persova M.G. Reshenie trekhmernykh statsionarnykh zadach elektrorazvedki na neregulyarnykh parallelepipeidal'nykh setkakh [The solution of threedimensional stationary problems EM survey on irregular parallelepipedal grids]. Vestnik Irkutskogo gosudarstvennogo tekhnicheskogo universiteta - Bulletin of Irkutsk State Technical University, 2004, no. 1 (17), pp. 22-33.

Kondratyev Nikolay Vladimirovich, an assistant lecturer at the department of applied mathematics, Novosibirsk State Technical University. His research interests are currently focused on the development and optimizations of parallel programs, acceleration of numerical modeling on CPU and GPU devices, development and implementation of distributed calculation systems for numerical modeling. He is the author of 14 scientific papers. E-mail: kondratyev@ami.nstu.ru.

Kiselev Dmitry Sergeevich, a postgraduate student, an assistant lecturer at the department of applied mathematics, Novosibirsk State Technical University. His research interests are currently focused on finite element modeling. He is the author of more than 20 scientific papers. E-mail: harlequin_00@mail.ru.

Vagin Denis Vladimirovich, Candidate of Sciences (Eng.), an associate professor at the department of applied mathematics, Novosibirsk State Technical University. His research interests are currently focused on finite element modeling of electromagnetic fields. He is the author of more than 80 scientific papers. E-mail: vdv_wk@mail.ru 
Persova Marina Gennad'evna, Doctor of Sciences (Eng.), professor, a professor at the applied mathematics department, Novosibirsk State Technical University. Her research interests are currently focused on finite element modeling and knowledge-intensive software for modeling and supporting technologies. She is the author of more than 150 scientific papers. E-mail: persova@ami.nstu.ru

Soloveichik Yuri Grigorievich, Doctor of Sciences (Eng.), professor, head of the department of applied mathematics, Novosibirsk State Technical University. His research interests are currently focused on finite element modeling and knowledge-intensive software for modeling and supporting technologies. He is the author of more than 150 scientific papers. E-mail: soloveychik@ami.nstu.ru.

Кондратьев Николай Владимирович, аспирант кафедры прикладной математики Новосибирского государственного технического университета. Основное направление научных исследований - разработка и оптимизация параллельных программ решения СЛАУ, полученных в результате конечноэлементной аппроксимации в задачах электромагнетизма в системах с общей и разделяемой памятью. Автор и соавтор 14 научных работ. E-mail: kondratyev@ami.nstu.ru

Киселев Дмитрий Сергеевич, ассистент кафедры прикладной математики Новосибирского государственного технического университета. Основное направление научных исследований - конечноэлементное моделирование. Автор и соавтор более 20 научных работ. E-mail: harlequin_00@mail.ru

Вагин Денис Владимирович, кандидат технических наук, доцент кафедры прикладной математики Новосибирского государственного технического университета. Основное направление научных исследований - конечноэлементное моделирование электромагнитных полей. Автор и соавтор более 80 научных работ. E-mail: vdv_wk@mail.ru

Персова Марина Геннадьевна, доктор технических наук, профессор, профессор кафедры прикладной математики Новосибирского государственного технического университета. Основное направление научных исследований - конечноэлементное моделирование и наукоемкое программное обеспечение для моделирования и сопровождения технологий. Автор и соавтор более 150 научных и учебно-методических работ. E-mail: persova@ami.nstu.ru

Соловейчик Юрий Григорьевич, доктор технических наук, профессор, членкорреспондент САН ВШ, заведующий кафедрой прикладной математики Новосибирского государственного технического университета. Основное направление научных исследований - конечноэлементное моделирование и наукоемкое программное обеспечение для моделирования и сопровождения технологий. Автор и соавтор более 150 научных и учебно-методических работ. E-mail: soloveychik@ami.nstu.ru 
DOI: $10.17212 / 1814-1196-2018-4-59-78$

\title{
Исследование эквивалентности влияний переменной толщины и проводимости при трехмерной обработке данных аэроэлектроразведки в сложных средах
}

\author{
Н.В. КОНДРАТЬЕВ ${ }^{a}$, Д.С. КИСЕЛЕВ \\ Ю.Г. СОЛОВЕЙЧИК
}

630073, РФ, г. Новосибирск, пр. Карла Маркса, 20, Новосибирский государственный технический университет

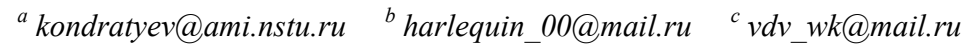

dpersova@ami.nstu.ru esoloveychik@ami.nstu.ru

Работа посвящена проблеме обработки данных аэроэлектроразведочных работ с целью разработки рекомендаций к параметризации геологической среды для выполнения геометрических 3D-инверсий аэроданных. Исследования проводятся с использованием конечноэлементного 3D-моделирования нестационарных электромагнитных полей, возбуждаемых расположенной на вертолете установкой, в сложных средах, с последующей 3D-инверсией синтезированных аэроданных. Геоэлектрические модели, выбранные для исследований, были взяты характерными для рассмотренного класса аэроэлектроразведочных работ в средах с рельефом и проводящим, неоднородным по проводимости и толщине верхним слоем, являющимся, по сути, мешающим фактором, и расположенным под ним слабопроводящим слоем с целевыми проводящими телами. Показано, что если изменения толщины верхнего слоя не превышают $30 \ldots 35$ м, при проведении 3D-инверсии, как минимум на ее первом этапе, верхний слой может подбираться как эквивалентный с постоянной (но подбираемой) толщиной, т. е. при параметризации верхнего слоя в вектор искомых параметров при решении обратной задачи можно включать только латеральные границы 3D-неоднородностей, их проводимости и толщину слоя, описываемую одним параметром. Также показано, что если на изучаемой площади изменения толщины верхнего слоя являются более существенными, его нижнюю границу следует определять более детально, поскольку в противном случае вполне могут быть пропущены в следующем целевом слое поисковые объекты с откликами порядка $15 \ldots 20 \%$ от суммарных сигналов, которые при более точном восстановлении верхнего слоя могут быть достаточно уверенно выявлены.

Ключевые слова: аэроэлектроразведка, численное 3D-моделирование, геометрические 3D-инверсии, электромагнитное поле, зондирование во временной области, рельеф, эквивалентные решения, обратные задачи

\section{СПИСОК ЛИТЕРАТУРЫ}

1. Three-dimensional resistivity characterization of a coastal area: application of grounded electrical-source airborne transient electromagnetic (GREATEM) survey data from Kujukuri Beach, Japan / S. Abd Allah, T. Mogi, H. Ito, A. Jomori, Y. Yuuki, E. Fomenko, K. Kiho, H. Kaieda, K. Suzuki, K. Tsukuda // Journal of Applied Geophysics. - 2013. - Vol. 99. - P. 1-11.

* Статья получена 09 марта 2018 г.

Работа выполнена при финансовой поддержке гранта Президента Российской Федерацчии для государственной поддержки молодых российских ученых - кандидатов наук (№ гранma MK-5010.2018.9). 
2. Artificial neural networks for removal of couplings in airborne transient electromagnetic data / K.K. Andersen, C. Kirkegaard, N. Foged, A.V. Christiansen, E. Auken // Geophysical Prospecting. 2016. - Vol. 64, N 3. - P. 741-752.

3. Dehiya R.S.A., Gupta P.K., Israil M. Interpretation of CSEM data using 2D block inversion algorithm // 22nd EM Induction Workshop. - Weimar, Germany, 2014.

4. Grayver A.V. Parallel three-dimensional magnetotelluric inversion using adaptive finiteelement method. Part I. Theory and synthetic study // Geophysical Journal International. - 2015. Vol. 202, N 1. - P. 584-603.

5. Haber E., Schwarzbach C. Parallel inversion of large-scale airborne time-domain electromagnetic data with multiple OcTree meshes // Inverse Problems. - 2014. - Vol. 30, N 5.

6. Liu Y., Yin C. 3D inversion for multipulse airborne transient electromagnetic data // Geophysics. - 2016. - Vol. 81, N 6. - P. E401-E408.

7.3D parametric hybrid inversion of time-domain airborne electromagnetic data / M.S. McMillan, C. Schwarzbach, E. Haber, D.W. Oldenburg // Geophysics. - 2015. - Vol. 80, N 6. P. K25-K36.

8. Multiple body parametric inversion of frequency- and time-domain airborne electromagnetics / M.S. McMillan, C. Schwarzbach, E. Haber, D.W. Oldenburg // SEG Technical Program Expanded Abstracts. - 2016. - Vol. 35. - P. 846-851.

9. Application of the marine circular electric dipole method in high latitude Arctic regions using drifting ice floes / V. Mogilatov, M. Goldman, M. Persova, Y. Soloveichik, Y. Koshkina, O. Trubacheva, A. Zlobinskiy // Journal of Applied Geophysics. - 2016. - Vol. 135. - P. 17-31.

10. Oldenburg D.W., Haber E., Shekhtman R. Three dimensional inversion of multisource time domain electromagnetic data // Geophysics. - 2013. - Vol. 78, N 1. - P. E47-E57.

11. Geometrical nonlinear 3D inversion of airborne time domain EM data / M.G. Persova, Y.G. Soloveichik, Y.I. Koshkina, D.V. Vagin, O.S. Trubacheva // Near Surface Geoscience 2016: 1st Conference on Geophysics for Mineral Exploration and Mining. - Barcelona, Spain, 2016.

12. Methods and algorithms for reconstructing three-dimensional distributions of electric conductivity and polarization in the medium by finite-element 3D modeling using the data of electromagnetic sounding / M.G. Persova, Y.G. Soloveichik, G.M. Trigubovich, M.G. Tokareva // Izvestiya. Physics of the Solid Earth. - 2013. - Vol. 49, N 3. - P. 329-343.

13. Transient electromagnetic modelling of an isolated wire loop over a conductive medium / M.G. Persova, Y.G. Soloveichik, G.M. Trigubovich, D.V. Vagin, P.A. Domnikov // Geophysical Prospecting. - 2014. - Vol. 62, N 5. - P. 1193-1201.

14. Multidimensional processing of the airborne EM data in the complex media / M.G. Persova, Y.G. Soloveichik, D.V. Vagin, P.A. Domnikov, D.S. Kiselev, Y.I. Koshkina, E.I. Simon // Engineering and Mining Geophysics 2018. - Kazakhstan, Almaty, 2018.

15. Schenk $O$., ت̈artner $K$. Solving unsymmetric sparse systems of linear equations with PARDISO // Future Generation Computer Systems. - 2004. - Vol. 20, N 3. - P. 475-487.

16. Singh A.D.R., Gupta P.K., Israil M. Development of block Inversion algorithm and its comparison with cell inversion schemes // 22nd EM Induction Workshop. - Weimar, Germany, 2014.

17. Finite-element solution to multidimensional multisource electromagnetic problems in the frequency domain using non-conforming meshes / Y.G. Soloveichik, M.G. Persova, P.A. Domnikov, Y.I. Koshkina, D.V. Vagin // Geophysical Journal International. - 2018. - Vol. 212, N 3. - P. 21592193.

18. Yang D., Oldenburg D.W. Three-dimensional inversion of airborne time-domain electromagnetic data with applications to a porphyry deposit // Geophysics. - 2012. - Vol. 77, N 2. P. B23-B34.

19. Yang D., Oldenburg D.W., Haber E. 3-D inversion of airborne electromagnetic data parallelized and accelerated by local mesh and adaptive soundings // Geophysical Journal International. 2014. - Vol. 196, N 3. - P. 1492-1507.

20. Применение неконформных сеток с шестигранными ячейками для 3D-моделирования технологий аэроэлектроразведки / М.Г. Персова, Ю.Г. Соловейчик, Д.В. Вагин, Д.С. Киселев, 
Н.В. Кондратьев, Ю.И. Кошкина, О.С. Трубачева // Доклады Академии наук высшей школы Российской Федерации. - 2018. - № 1 (38). - С. 64-79.

21. Персова М.Г., Трубачева О.С. О подходе к решению обратной задачи вызванной поляризации при восстановлении границ аномальных по поляризуемости объектов // Доклады Академии наук высшей школы Российской Федерации. - 2015. - № 3 (28). - С. 88-98.

22. Соловейчик Ю.Г., Рояк М.Э., Персова М.Г. Метод конечных элементов для решения скалярных и векторных задач. - Новосибирск: Изд-во НГТУ, 2007. - 896 с.

23. Соловейчик Ю.Г., Токарева М.Г., Персова М.Г. Решение трехмерных стационарных задач электроразведки на нерегулярных параллелепипеидальных сетках // Вестник Иркутского государственного технического университета. - 2004. - № 1 (17). - С. 22-23.

For citation:

Kondratyev N.V., Kiselev D.S., Vagin D.V., Persova M.G., Soloveichik Yu.G. A study of equivalence of influences of varying thickness and conductivity in 3D-processing of airborne electromagnetic data in complex media. Nauchnyi vestnik Novosibirskogo gosudarstvennogo tekhnicheskogo universiteta - Science bulletin of the Novosibirsk state technical university, 2018, no. 4 (73), pp. 59-78. doi: 10.17212/1814-1196-2018-4-59-78.

Для цитирования:

Исследование эквивалентности влияний переменной толщины и проводимости при трехмерной обработке данных аэроэлектроразведки в сложных средах / Н.В. Кондратьев, Д.С. Киселев, Д.В. Вагин, М.Г. Персова, Ю.Г. Соловейчик // Научный вестник НГТУ. - 2018. № 4 (73). - С. 59-78. - Яз. англ. - doi: 10.17212/1814-1196-2018-4-59-78.

ISSN 1814-1196, http://journals.nstu.ru/vestnik Science Bulletin of the NSTU Vol. 73, No 4, 2018, pp. 59-78 